\title{
BILINGUALISM AND DEVELOPMENT: A PSYCHOLOGICAL APPROACH ${ }^{*}$
}

Research on the relation between bilingualism and psychological development can be structured in many ways. This review will focus on two issues: first, empirical evidence that bilingualism is associated with several aspects of psychological development; and second, holistic and partial explanations for the influence of bilingualism on personality development, whether in general or in particular. Holistic explanations usually begin by distinguishing between additive and subtractive bilingual situations, and then hypothesizing as a result a broad spectrum of behavioural changes in personality. An attempt has been made to illuminate this connection by using concepts from the psychology of learning and motivation. Partial explanations can be found in concepts such as semi-lingualism vs. surface- and cognitive linguistic competence; and in several hypotheses, such as the interdependence of language proficiency in bilinguals, and Cummins' threshold hypothesis. In conclusion, the accumulated knowledge about bilingual development will be suggested as a resource for better understanding issues of psychological development in general. Future research should concentrate especially on mechanisms that best reverse language shift, on bilingualism and aging, bilingualism and emotions, and on bilingual episodic (autobiographical) memory.

Keywords: bilingualism, psychological development, costs and benefits of bilingualism

\section{INTRODUCTION}

The study of bilingualism's psychological aspects has more than a century long history (Dewaele, 2015). Although the scientific knowledge gained from this research can offer important findings for many psychological disciplines (especially significant guidelines for a broader realization of human potentials in general), it remains inadequately covered in the psychological media. This article intends to achieve two purposes: (I) to give a short overview of investigations on psychological aspects of bilingualism in a historical perspective, aiming to demonstrate that bilingualism is significantly associated with many psychological variables, and

\footnotetext{
*Lajos Göncz: goencz.lajos@gmail.com

The paper was written within the projects No 179010 and No 47020, supported by

the Ministry of Education, Science and Technological Development of the Republic of Serbia.
} 
(II) to summarize some more holistic or partial explanations for these connections, an issue which has thus far been discussed mostly within the contexts of the sociolinguistic and the psycholinguistic aspects of bilingualism.
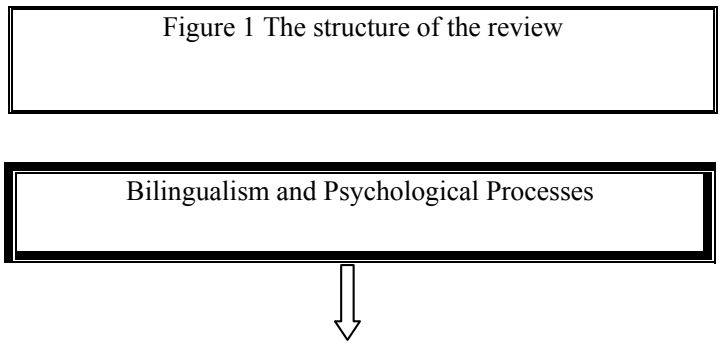

I. Evidence in empirical studies that bilingualism is related to:

General intelligence; verbal and nonverbal I.Q.; concept formation; analogical reasoning; cognitive flexibility; creativity; vocabulary size; grammar errors; meta-linguistic abilities; executive functions; cognitive aging; storing, retaining and recalling information; autobiographical memory; school achievement; content knowledge; attitudes toward secondlanguage speakers; communicative sensitivity; mental wellbeing.

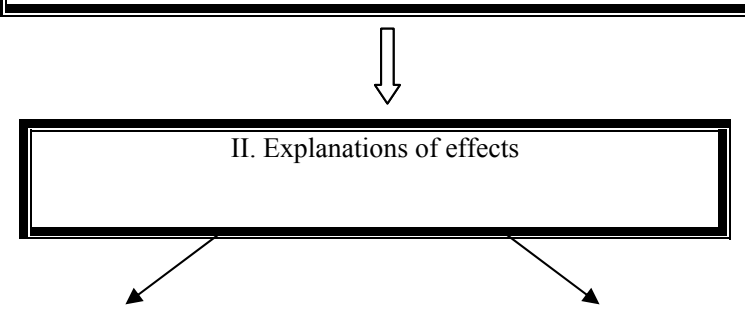

\begin{tabular}{|l|c|}
\hline \multicolumn{3}{|c|}{ Holistic } \\
\hline -additive/subtractive distinction: \\
\hline -notions from psychological and \\
related disciplines, especially of \\
psychology of learning and \\
motivation & \\
& \\
\end{tabular}

\begin{tabular}{|ll|}
\hline \multicolumn{2}{|c|}{ Partial } \\
\hline \multicolumn{2}{|c|}{$\sim$ based on: } \\
\hline Concepts: & Hypothesis: \\
-semilingualism & -developmental \\
\hline -proficiency of & interdependence \\
\hline language & hypothesis \\
\hline competence & -threshold \\
\hline (BICS, CALP) & hypothesis \\
\hline
\end{tabular}


The structure of this review is outlined in Figurel. The first section will begin with an overview of the empirical evidence for associating bilingualism with cognitive, social and emotional behaviour, and educational efficacy. The second part will begin with holistic explanations of how bilingualism and other features of heterogeneous settings (such as biculturalism) can influence mental processes and behaviour in general, and will expand the dependent variable to the cognitive, linguistic and cultural benefits or disadvantages of bilingualism. Next, some partial explanations of bilingualism's will follow, regarding those aspects of behaviour which have been the most thoroughly researched. These explanations are linked to the following concepts and hypotheses: double semi-lingualism, surface and cognitive linguistic competence, the hypothesis of the interdependence of language proficiency in bilinguals and Cummins' threshold hypothesis.

The term holistic explanation refers to an explanation that takes a contextualised approach to the possible influences of bilingualism on mental states, while emphasizing the role of environmental factors (e.g. learning context, language status and cultural factors) in becoming bilingual. In partial explanations, the key factor is the level of proficiency in the two languages, without emphasis on the socio-cultural context. In other words, the distinction between a holistic and a partial explanation depends on the level of analysis, i.e. whether or not bilingualism is conceived of as a sociolinguistic or a psycholinguistic phenomenon.

The holistic approach to bilingualism often emphasizes the difference between additive and subtractive bilingual situations, whether groups and their members in a heterogeneous community are classified hierarchically by language, ethnicity, culture or religion. In an additive situation the groups enjoy approximately equal status, while a subtractive situation means a preferential environment for one of the groups. With respect to the psycholinguistic perspective on bilingualism, language proficiency is the most important, with a key distinction between balanced bilingualism (having roughly the same competence, high or low, in both languages), and unbalanced or dominant bilingualism (having significantly higher competence in one of the two languages). Groups labelled as 'balanced' in most empirical studies usually have high proficiency in both languages, rendering the term elitist.

\section{EMPIRICAL EVIDENCE OF BILINGUALISM'S RELATION TO SEVERAL ASPECTS OF BEHAVIOUR}

\section{Early studies}

Since their beginning in the 1910s, empirical studies have become increasingly more frequent. The first wave of research lasted until the 1960s. Monographs from this period, mostly written by linguists (e. g. (Ronjat, 1913), focused on children who grew up under the early influence of two or more languages inside or outside the family - a case study approach that exceeds the scope of the present article. 
Researchers in North America and Europe were mainly interested in the relationship between bilingualism and performance on intelligence tests, speech development and academic achievement. Several empirical studies compared groups of bilingual people predominantly coming from immigrant or indigenous minorities who spoke various languages (Spanish, French, Irish, Welsh, Chinese, Japanese, etc.) as their first language and (mostly) English as the second, with monolingual English groups in a majority position. The results showed, with only a few exceptions, that monolinguals had an advantage over bilinguals in all the aforementioned indicators. For example, Cöncz (1981) concluded from a review of relevant research, examining the relation between bilingualism and intelligence, that in the studies conducted between 1922 and 1962 monolingual children showed higher scores than bilinguals in verbal and often also in nonverbal intelligence tests, while in a small number of studies there were no significant differences, and in only a few studies bilingual children outperformed their monolingual counterparts. Darcy (1953) also concluded in her review that "the general trend has been toward the conclusion that bilinguals suffer from a language handicap when measured by verbal tests of intelligence (p. 50)". For a more detailed overview of the early studies see also e.g. Lee, 1996.

Macnamara (1966) reviewed early empirical studies on the speech development of bilinguals. He found that bilingual children, in comparison to monolinguals, demonstrated lower performance in articulation, vocabulary, written composition, and reading, used shorter sentences and made more grammatical errors. $\mathrm{He}$ claimed that bilingual children's poor academic performance and lower verbal intelligence was a result of a "balance effect". There was, in his view, a consistent negative correlation between the levels of proficiency in the bilinguals' two languages where a higher proficiency in the second language necessitates a loss in proficiency in the first language. McNamara's "balance effect" is very similar to the notion of semilingualism, or a lack of competence in both languages. From today's perspective, he holds the monolinguist subtractive view that one language is the norm for human beings. According to Cook (1997: 2008), because the option between monolinguist subtractive and multilinguist additive view is rooted in preconceptions, it becomes an ideological issue.

Many researchers (e.g. Cummins 1976; Göncz, 1985; Hakuta, Ferdman \& Diaz, 1986; Lee, 1996) have pointed to methodological problems associated with the early research. They claim that in the early period there was an inadequate balance of relevant factors between the groups, and that the differences were attributable not to bilingualism, but rather to other factors. These included an incorrect assessment of the testing language, which led to lower results among bilinguals whose English was weaker, and the comparison of middle-class English monolinguals to low-status bilinguals.

The Peal and Lambert study of 1962 was a turning-point in which the results of bilinguals surpassed those of monolinguals, even in verbal intelligence tests. They controlled for variables inadequately addressed previously. Their "balanced 
bilingual" group of fourth graders who were equally (high or low) proficient in French and English was compared to a similar monolingual French group in three intelligence tests. Grosjean (1982) summarized the main results of this study as follows:

The bilinguals scored higher on verbal and nonverbal IQ tests. Subtests showed that bilinguals had a more diversified structure of intelligence and more flexibility in thought: greater cognitive flexibility, greater creativity, and greater divergent thought. In addition, bilinguals were ahead in content work at school, and their attitudes toward English Canadians were more favourable than those of their monolingual French counterparts (p. 221).

Although Macnamara (1966) criticized the sampling procedure, which he believed favoured the bilinguals by inadvertently selecting brighter bilingual children, in the authors view, their sample of subjects was not biased; the bilinguals only had to approach an equally good or poor balance of skills in their two languages (Lambert \& Anisfeld, formerly Peal, 1969). Regarding the direction of causality, the authors wrote: "It is not possible to state from the present study whether the more intelligent child became bilingual or whether bilingualism aided his intellectual development, but there is no question about the fact that he is superior intellectually" (Peal \& Lambert, 1962, p. 20).

Hakuta \& Diaz (1985), who also investigated the issue of causality, concluded that it is bilingualism that leads to enhanced cognitive development and not the other way around. However, Takakuwa (2005) in his methodological critique argues that "bilingualism is a matter of degree and should be treated as a continuous variable" (p. 2226). He thinks that, in reality, Peal and Lambert actually compared intellectually inferior and superior groups at the lower and higher ends in the same distribution of bilinguals rather than in the two different distributions of bilinguals and monolinguals. His conclusion is, that

it is unknown whether bilingualism has an effect, if any, on children's cognitive development or whether cognitively advanced children can become bilingual more easily...studies utilizing a much more rigorous analysis are called for in the research on bilingualism (p. 2229).

\section{The impact of the Peal and Lambert study: bilingualism and development in additive vs. subtractive situations-benefits and costs of bilingualism}

The Peal and Lambert study, despite criticism, had a great impact on the field. It also highlighted the non-existence of "bilingualism in general" and the various outcomes of different types of bilingualism. The study also stressed that results should be interpreted within a wider theoretical framework. Afterwards more consideration was given to the standpoints developed concerning the relationship 
between speech and thinking as well as opinions on the possible influences of multi-layered environmental factors including.

Thanks to later empirical studies, conducted with greater methodological sophistication and in the rising new theoretical framework, it has become increasingly obvious that the influence of bilingualism on several aspects of behaviour (i.e. different aspects of general cognitive, speech, social and emotional development and educational efficacy) depends greatly on the social situation and the type of bilingualism that develops under its influence, with bilingual competence determining quality of effect.

The results of numerous investigations in predominantly additive situations seem to suggest that early bilingualism strengthens the role of speech in the development of thinking, and a multi-layered socio-cultural environment promotes a greater differentiation of capacities. As early as a decade and a half ago, Cummins (1999) stated that "there are well over 100 empirical studies carried out during the past 30 years or so that have reported a positive association between additive bilingualism and students' linguistic, cognitive, or academic growth" (p.127). For example, the studies of Liedtke \& Nelson (1968) and Bain (1974) display bilingual children's superior performance on concept formation tasks. Balkan (1970) found a positive relationship between bilingualism and the ability to restructure perceptual solutions, and Cummins \& Gulutsan (1974) and Diaz (1985) between bilingualism and analogical reasoning ability. Subjects in the Diaz study were required to complete sentences like this: The princess is beautiful, the monster is . In a test of divergent or creative thinking subjects had to generate a list of solutions to a problem or of uses for an object ("How many unusual uses can you think of for a brick?"). Cummins \& Gulutsan (1974) and Landry (1974, for a review of this literature, see Ricciardelli, 1992), and more recently May, Hill \& Tiakiwai (2004), found the replies of bilingual children to be more original. In several studies (Genesee, Tucker \& Lambert, 1975; Ben-Zeev, 1977; Mohanty, 1994) it was also discovered that bilinguals demonstrated more communicative sensitivity, meaning that they had an enhanced sensitivity to listeners' needs.

Göncz $(1981,1985)$ compared the performance of monolingual, dominant bilingual and balanced bilingual six and ten year old Hungarian children (the bilinguals knew and used Serbian to different degree in addition to Hungarian), equalized in relevant factors, in more than twenty indicators of cognitive and speech development. In fact, a kind of "within bilingual" design was used, because the monolingual group had a very limited knowledge in the second language, but it was not used outside the classroom lessons for communicational purposes. At the preschool level, he found that the monolingual group performed better on the PPVT (Peabody Picture Vocabulary Test). In the PPVT the respondents are shown four pictures and must indicate which of the four corresponds to a name spoken by the experimenter. However, at the age of ten, the balanced bilingual group achieved the same results in their first language on a similar receptive vocabulary test as the monolinguals did in their only language. The younger balanced bilinguals 
outperformed the monolinguals in metalinguistic development. An example of this was the Symbol-Substitution Test (which measures how strong the link is between the word and its meaning), where they accepted the possibility that an object can be named with a different word more often than monolinguals did. For example, if a "pencil" is called "book" it can be sharpened, and with such a "book" one can write. In the same study, in general intelligence, measured with Raven's Progressive Colour Matrices Test at preschool age, the monolingual boys (but not girls) performed better than the bilingual groups. By the age of ten, the results on nonverbal general intelligence tests were the opposite, favouring the balanced bilingual group. The older balanced bilingual group also preferred more sentences with plural concord, which is less desirable in Hungarian from a normative point of view. (Hungarian uses singular number concord very often in cases where Indo-European languages, like Serbian, use plural). In other words, they were less aware of the grammar of their standard language than the monolingual group. This digression from the codified language norms in bilinguals can be attributed to the use of contact variants of their languages, meaning language variants governed by the norms of the two languages. [Recent sociolinguistic research holds that such results are interpretable in terms of the language situation of bilingual speakers in minority communities. Their smaller vocabulary and digression from grammatical correctness can be attributed to drawbacks stemming from living in subtractive bilingual situation. They indicate language attrition caused by the restricted use of the mother tongue in certain spheres of life (Göncz \& Vörös, 2005)].

In one of the more recent overviews on the effects of bilingualism, Bialystok (2009) argues that bilingualism enhances attention (executive) control processes and conflict resolution, because "bilingual language production requires the constant involvement of the executive control system to manage attention to the target language" (p. 7). In her view, bilinguals have developed a set of high-level cognitive abilities necessary for goal directed behaviour that control and regulate many lower-level abilities and behaviour. These executive functions include the ability to initiate and stop actions, to monitor and change behaviour as needed, and to plan future behaviour when faced with novel tasks and situations. They also enable people to make alternative plans quickly when unusual events arise, and to inhibit inappropriate reactions. Because bilingual experience enhances such abilities, they perform better than monolinguals in the Simon and Stroop tasks, in which appropriate attention control to the target by inhibiting the interfering option is required. [In the Simon task the test takers saw either a red or blue square flash on a computer screen and were instructed to depress one or the other shift keys depending on which colour appeared. The reaction time is faster when the stimulus occurs in the same relative location as the response, even if the stimulus location is irrelevant to the task. In the Stroop task a colour name such as blue, red, etc. is printed in a different colour expressed by the word's semantic meaning (e.g. the word "red" printed in blue ink). Naming the colour of the print takes longer than 
when the meaning of the word is incongruent with its ink colour]. In other words, bilingualism significantly accelerates children's ability to selectively attend to relevant information and inhibit attention to misleading information or competing responses. Although some executive functions decline with age, Bialystok holds that this bilingual advantage also persists in older adults, together with a delay in the development of senility and dementia (Bialystok, 2001; Bialystok, Craik, Klein \& Visvanathan, 2004; Bialystok, Craik, \& Ryan, 2006; Bialystok, Craik, \& Freedman, 2007; Bialystok, 2015; Klein, 2015). There is also a growing body of research that demonstrated bilingual adventages including infants with supporting neuroimaging evidence (Bialystok, Craik, Binns, Ossher \& Freedman, 2014). So it seems that bilingualism has an impact asross the life span. [However, some researchers are far more cautious regarding this issue: as Schrauf(2008) pointed out, "cognitive aging and bilingualism is a research area in its infancy" (p. 105)].

\section{Bilingual memory research}

Another fruitful field of bilingual research which has yielded empirical evidence that bilingual experience might be a significant factor in cognitive functioning is the field of bilingual memory. Typically seen as a counterpart to learning, memory is one's mental ability to store, retain and recall information. Researchers of bilingual memory are interested in characteristics of memory organization (encoding, storage and retaining of lexical information), and in recalling processes (lexical access or word-finding) in bilinguals.

This topic is approached from a psycholinguistic and neurolinguistic perspective as well, constructing models of bilingual memory. Despite a large number of such studies no clear-cut results have been found (see, for example an overview of so called hierarchical and connectionist models by Heredia, 2008). Hierarchical models, like word association, concept mediation, mixed, revised, and re-revised hierarchical models, are primarily occupied with the organization of bilingual memory representation, whereas connectionist models deal with the problem of how organization might have come about as a result of language acquisition. As French \& Jacquet (2004) pointed out, there is a "more-or-less general agreement on the necessity of separating conceptual and lexical levels, the conceptual level being seen as shared by both languages with lexical representations being specific to each language" (pp. 87-88). In other words, bilingual memory is thought to be composed of a common conceptual store, which contains abstract representation about the world, and two separated but interconnected lexical stores, containing our lexical and grammatical knowledge. According to hierarchical models (e.g. Li et al., 2009), the link between these stores tends to be different depending on the levels of second language proficiency and the information in one language is available in the other only through a translation process, also known as an independent lexicon storage view. 
On the other hand, Grosjean (1994) and Paradis (1997; 2004) are proponents of the one-lexicon, or interdependent storage view. They state that linguistic information is stored in one "large" bilingual lexicon, in which each language is represented by a subset of units or language networks belonging to each language, because a label is attached or "tagged" to each

word in the store to indicate the language it belongs to. Both networks are subsets, enclosed in a larger set, and they allow a bilingual to speak each language independently from one another. But at the same time, the networks are also interconnected in the sense that the monolingual speech of bilinguals often shows interference from the other language, as is the case in code-switching and borrowing. With respect to the linguistic organization of the bilingual brain, that is of how the lexical meaning and corresponding conceptual representations are materialized in the brain (a neurolinguistic perspective), Paradis (1997) concludes that in the brains of bilinguals, the two languages are neurofunctionally independent, but their representation is not anatomically distinct, meaning the bilingual's languages are not stored in completely different locations, and do not show evidence of differential lateralization.

Based on research into bilingualism and emotions, Pavlenko (2008) provides a framework for the mental representation of emotion concepts in the two languages of the bilingual. She calls for several modifications to the current models of bilingual lexicon; for example, she argues that ,emotionality is an important feature of the bilingual lexicon, where different languages and word types display different levels of emotionality...differential emotionality affects code-switching and language choice in bi- and multilinguals" (p. 147). Dewaele (2008) also thinks, that incomplete understanding of the emotionality of an emotion word, or an emotion-laden word in the second language might be more discomforting than grammatical errors.

Despite the progress that has been made in recent years concerning bilingual memory research, it is not clear whether bilingualism should affect the development and functioning of memory in general or of some memory processes (sensory, short-term or working, and long-term memory) or memory types (declarative or explicit and procedural or implicit memory). Bialystok (2009) believes that bilingualism might enhance working memory, which requires effective inhibition of distracters and this is better controlled in bilinguals. Because working memory is considered to be part of executive functioning, which might be enhanced as a consequence of bilingualism, Bialystok hypothesizes that it is possible for this capacity to be increased in bilinguals.

According to Altarriba (2002), bilinguals have two sets of culture and language specific information. The native language might encode events regarding early development, whereas the second language is more connected to adulthood. She concluded that "when bilinguals engaged in processes that require language encoding, storage and retrieval, it appears that the use of both languages might reveal more information and more varied information than the use of just one"(s. 
p.). Schrauf (2000) also noted that memories from childhood and adolescence experienced in the native language are emotionally more loaded when recalled in that language. These findings emphasize the importance of researching the connections between bilingual experiences and episodic memory, which is the memory of autobiographical events that can be explicitly stated. (Episodic memory, together with semantic memory makes up declarative or explicit memory that store facts that can be consciously declared. Its counterpart is procedural or implicit memory, which applies to skills). Schrauf et al. (2003) developed a model of bilingual episodic memory by integrating previous empirical findings on this topic (besides the already mentioned, also like those of Marian \& Neisser, 2000) with research results on the relation between monolingual context-independent semantic and episodic memory.

\section{Bilingualism and meta-linguistic awareness}

In the past few decades, much research has been conducted into discovering the relationship between early bilingualism and the development of meta-linguistic awareness. Meta-linguistic awareness may generally be defined as the ability to treat the language itself as an object of thought. As early as 1949, Leopold observed that early access to two languages could lead to a more rapid separation of name and object. This is in accordance with the ideas of theoreticians that one of the important roles of language in the mental ontogenesis is to direct thought towards the essential features of the environment. In early bilingualism, this directing is in the form of naming the same objects or events using the two languages' different signs for them. Such repeated experience creates conditions which bring about earlier awareness on the part of the child that the name of an object is not inseparably linked to the object itself, and can result in earlier disappearance of vocal and semantic linking. The consequences could be far-reaching: thought becomes more independent from speech and focused towards the essential attributes of objects while, at the same time, linguistic entities can find themselves at the centre of attention.

As Göncz \& Kodžopeljić (1991) stated, empirical verifications of Leopold's observation have confirmed that, in certain bilingual situations, the achievements of bilingual children in various aspects of metalinguistic development are different from those of monolingual children.

The results of several studies confirm this conclusion. For example, IancoWorrall (1972) compared an English-Afrikaans bilingual and two monolingual groups in English and in Afrikaans aged 4-6 and 7-9 years. She found that in the Semantic-Phonetic Preference Test the bilingual group choose the semantic response more often than did monolinguals, e.g. in a task like: "I have three words: cap, can and hat. Which is more like cap, can or hat?" they preferred "hat". Her bilingual respondents also accepted more often than their monolingual peers the possibility that things can change their names (A "cow" could be called "dog" and 
a "dog" "cow" if we assume that we are making up names). In another investigation, Göncz (1973) asked Hungarian-Serbian bilingual preschoolers and their monolingual peers questions like "Which word is longer: ox or mosquito?" (The longer word always denoted something smaller in comparison to the meaning of the shorter word). The results in this study were also in favour of the bilinguals. The Hebrew-English bilinguals in the study of Ben-Zeev (1977) outperformed monolinguals in tasks involving "symbol substitution" and similar tasks, and she reasoned that the link between the word and its meaning was less strong in bilinguals than in monolinguals and that they realize sooner the arbitrary nature of language. Cummins (1978) also found enhanced meta-linguistic awareness attributable to bilingualism, i.e. bilingual children were shown to have greater capacities to evaluate tautological and contradictory statements than monolingual children do. Furthermore, due to a considerable number of findings that metalinguistic awareness, primarily phonemic segmentation and certain types of word awareness, is connected with the acquisition of literacy (e.g. Downing \& Valtin, 1984; Göncz \& Kodžopeljić, 1991; Tsai \& Yaden, 2004), it is not surprising that researchers (e.g. Bialystok, 2001) have reviewed numerous investigations in which positive connections appeared between early bilingualism and reading acquisition.

\section{On some disadvantages of subtractive bilingual situations}

Disadvantages that may be linked to bilingual experience appear (mostly) in subtractive bilingual situations, where the stimulation of the development of the first language is not sufficient, or its use is limited. Bialystok (2009) found that "bilingual children control a smaller vocabulary than their monolingual peers and bilingual adults perform more poorly on rapid lexical retrieval tasks" (p. 3). Additionally, Ben-Zeev (1977) also noticed some delay in vocabulary and grammatical structures by Spanish-English bilingual children. Of course, from an additive multilinguist perspective, the question of vocabulary size remains disputable: is it the size of vocabulary of bilinguals only in the language of the monolingual group, or in their both languages taken together?

Drawbacks occur in the scholastic achievement of bilingual minority children in all situations when the schools disregard the bilingual students' home language and culture. As May and Hill (2003) concluded, such submersion programmes "are widely attested as the least effective educationally for minority language students (p. 14).

The results of a follow-up study on mental wellbeing and school achievement among school-aged Finnish-Swedish re-migrant children (Moilanen \& Myhrman, 1989; Moilanen \& Myhrman, 1989; Vuorenkoski et al., 1998; Vuorenkoski, Kuure, Moilanen, Penninkilampi \& Myhrman, 2000), and the findings concerning difficulties encountered by Hong Kong Chinese pupils studying in England, with English as the language of instruction (Berry \& Williams, 2004) also pointed to 
some unpleasant experience connected to bilingualism. Berry \& Williams' study showed that affirming oneself in a new environment is by no means easy. If one's sense of self is perceived to be endangered, distress may be felt, resulting in lower performance academically. The authors concluded that "learners have a far broader range of problems than simply linguistic ones and that they experienced deeprooted sociocultural and affective difficulties" (p. 131).

\title{
Summary of Empirical Evidence of Bilingualism's Relation to Several Aspects of Behaviour
}

In sum, results of empirical studies selected in this article to represent associations of bilingualism with many psychological processes, support the notion that the bilingual experience is an important factor in psychological development and functioning. They suggest that the study of bilingualism is much more complex than that of monolingualism. Its effects always depend on the interplay of numerous psychological, sociological and linguistic variables, while the methodology applied might also have a considerable impact on the outcome. Therefore, researchers in this field have to be acquainted with extremely diverse methods and tools for collecting and analyzing data from different disciplinary perspectives. (For the main methodological issues on researching bilingualism see, for example, Marian, 2008 and Wei \& Moyer, 2008).

\section{HOLISTIC AND PARTIAL EXPLANATAIONS FOR THE INFLUENCE OF BILINGUALISM ON PSYCHOLOGICAL DEVELOPMENT}

\author{
HOLISTIC EXPLANATIONS
}

\section{The additive-subtractive distinction}

In holistic explanations of bilingualism's influence on psychological development and functioning, particular emphasis has been placed on the additive-subtractive pair of concepts, in both communal and individual bilingualism. This distinction was introduced by Lambert (1975), and has yielded some acceptable explanations for the often contradictory results of empirical studies on the possible psychological effects of various bilingual situations.

It is important to note, that this dichotomy originally refers to social setting in which bilingualism is developed (additive and subtractive bilingual situation), and not to consequences of such situations on individuals or speech communities (additive or subtractive bilingualism). Avoiding this mixing of levels of analysis could be useful for fuller understanding of this dichotomy and its consequences. 
From a social perspective, this pair of concepts applies to the members of a heterogeneous community or group and their possible hierarchy according to language, ethnicity, culture or religion.

In an additive bilingual situation the nationalities, languages and cultures in a heterogeneous community are equally appreciated and all enjoy roughly equal status. Additive individual bilingualism, as a consequence of an additive situation in which the acquisition of both languages is a desirable goal, is not characterized by language shift; that is, one language is not acquired at the other's expense, but rather the second language develops in addition to the first, which is also retained. Personality development in an additive bilingual environment is more complex than in a monolingual setting, yet, in many respects, enables a fuller development of an individual's dispositions.

In a subtractive situation the environment confers preferential treatment on one of the ethnicities, languages or cultures. Here, the lower-status language is frequently exchanged for the language of preference; meaning that the language of higher status is learned to the detriment of the other, leading to inadequate competence in either languages, or double semilingualism. This can have consequences for other aspects of the personality, such as intellectual, social and emotional development, and learning ability (see later).

In reality, additive and subtractive situations are not mutually exclusive categories, but mark the opposing ends of a spectrum that includes several transitional forms. A heterogeneous environment always presents a range of additive and subtractive features.

For a long time, empirical support lent strong evidence to differential effects of additive and subtractive situations. Long \& Padilla (1970) found that children whose low status native language was valued and used in their families, performed better in school than children whose low status first language was neglected and substituted with a high status second language at home. Cummins (1984) claims that submersion programs in which the children's use of their mother tongue is discouraged or forbidden can lead to feelings of embarrassment and shame of one's own language and culture, and that in turn can lead to use of dominant language, abandonment of family language, and ensuing academic difficulties. He also quotes research which suggests students working in an additive bilingual environment succeed more than those whose native language and culture are devalued by their schools and by wider society (Cummins, 1994). Taking all of this into consideration, Lee (1996) concluded that "one must consider whether communities, be they schools, families, or society in general, view bilingualism as a desirable and valuable condition, or rather as unnecessary and of little value and importance" (p. 513). Bialystok (2001) also argues that the native language is instrumental in forming identity, and being required to speak a language that is not completely natural, may interfere with the child's construction of self. 


\section{Holisitic explanations of differential effects of additive-subtractive bilingual situations with concepts from different psychological disciplines}

With the additive-subtractive distinction in mind, we are now able to offer relatively plausible explanations for their differential effects by using concepts from different fields of psychology. In an additive situation, the speaker must discover the rules of functioning as well as learn language tools for both languages, thereby exerting greater intellectual effort and activating speech-functions that stimulate general intellectual development (Göncz, 1981). Many researchers (among them Piaget, 1964 and Vygotsky, 1962) stress that speech directs attention to various and important relations in the environment. As each language segments reality in its own manner (Whorf, 1956; for further information about linguistic relativity regarding linguistic and cultural specificity of conceptual representations in bilinguals see Pavlenko, 1999, and the peer commentaries on her views on bilingual memory in Bilingualism: Language and Cognition, 3(1), 2000, 5-30), the bilingual's attention takes into account more aspects of reality. Bilingualism and biculturalism, when accepted by the environment, can benefit development in additional ways: knowledge of two or more languages gives the speaker an appreciation of the cultural achievements of each speech community (Garcia, 2009), thereby reducing ethnocentrism, countering stereotypes, encouraging linguistic and cultural tolerance (Peal \& Lambert, 1962), and perhaps even facilitating conflict-resolution between the two cultures (Nguyen \& Benet-Martinez, 2007). Undoubtedly, certain components of a culture correlate with personality development, as childrearing methods vary across cultures, with each requiring the acquisition of behaviours suited to various times and situations. As a result, a person who is exposed to more than one culture develops different behaviours and traits from the person who is exposed to only one (Matsumoto \& Juang, 2008).

In contrast, in a subtractive bilingual situation in which bilingualism is unwelcome, social, emotional and linguistic development can suffer. If one language or culture is favoured in a heterogeneous environment, and this language or culture receives preferential treatment, while the other language is excluded or its use is greatly reduced, then members of the inferior language group receive the message from the environment that their language and culture is non-viable and undesirable, and should be neglected in order to achieve success in the society. If this attitude is intense and persists, the stigmatized language will naturally become superfluous or even despised. The upgraded language gains in attractiveness as it conveys a sense of achievement. From the standpoint of the psychology of learning, this explains language and culture shift: operant learning and classical conditioning come to the forefront.

In operant learning, behaviour (in this case language use) serves to reach a certain target. If the target is achieved (the individual receives positive reinforcement), then the behaviour leading to this success is reinforced; if not, the behaviour is weakened. Behaviour can also be inhibited by unpleasant 
consequences or punishment (as when the use of a language elicits disapproval from the environment). Avoidance and escape behaviour can also be considered rewarding, as they are the only ways to avoid or escape punishment. In the present case, this would mean avoiding or giving up the undesirable language. This is negative conditioning. As behaviour and consequences occur together in time and space, association is generated between the two: behaviour is conditioned by a negative or positive consequence, which either weakens it, by giving it a negative colouring, or strengthens it, by making it attractive. If we exchange an undesirable behaviour for a rewarded one, the same situation in future will elicit the desirable behaviour which is now reinforced. This is called positive deconditioning.

With this in mind, it is at least partly possible to explain why one language and culture may be exchanged for a socially preferred language and culture. Because the undervalued language and culture appear less able to achieve one's goals, and because unpleasant consequences attend their appearance, development slows and they recur with ever-decreasing frequency. Use of this language is conditioned by the distress attendant upon failure, lending it an even more unpleasant colouring. If the favoured language is offered as an alternative, and its use is rewarded, the individual will turn to it more often; that is, he or she will abandon behaviours that lead to failure and unpleasantness, exchanging them for behaviours that ensure award and success. Indeed, at the wider community level, people's behaviour is shaped by reward, punishment and disregard: they exchange inferior behaviours for more rewarding ones. A person's susceptibility to such influences depends on personality, with some people more likely than others to internalize environmental prohibitions or disincentives.

Motivational psychology can also help in understanding some other psychological influences of subtractive bilingualism. People fulfil their needs in various setting - family, kindergarten, school, the workplace, etc. If these environments obstruct or prevent people from satisfying their needs, they will become frustrated and experience anxiety, insecurity, fear, anger and aggression. Cumulative and lasting frustrations can lead to personality disorders, neurosis and behavioural abnormalities, with such people either withdrawing or lashing out.

In highly subtractive bilingual situations, obstacles are more frequent, creating situations that affect the speaker of the undesirable language, and triggering neurotic or psychosomatic processes. According to some researchers (such as Hódi, 1992), this may explain the significant correlation of psychosis and suicide with ethnic status in certain heterogeneous regions. The likelihood of frustration is clearly greater in a strongly subtractive bilingual situation; this creates the conditions for personality disorders, especially when other conditions for personality development are also unfavourable. Subtractive or additive bilingual situations do not exist in a pure form in any heterogeneous community, but one of the types may be dominant, thereby creating the 
conditions for more differential forms of personality development and behaviour, at least in relation to the group receiving preferential treatment.

\section{PARTIAL EXPLANATIONS}

\section{Semilingualism}

Researchers of bilingualism use various concepts and hypotheses to interpret the development of speech and intellectual functioning in bilinguals. One of these concepts is semilingualism which is often equated with doublesemilingualism and considered to be exclusive to bilinguals. According to Skutnabb-Kangas \& Toukomaa (1976), in such a state the bilingual is less competent in both languages than a monolingual speaker of either. The term is also present in Cummins' (1976), threshold hypothesis (see below). He believed that immigrant children might experience attrition of the first language before learning the second. Semilingualism has sparked heated debates: for Martin-Jones \& Romaine (1986) it is a "half-baked theory of communicative competence", MacSwan (2000) found no evidence for support for it, Garcia (2009) thinks that the notion contributes to linguistic stigmatization and is rooted in "the obsession with monolinguals as the norm of reference" (p.59).

Although many scholars today no longer consider the notion as a linguistic but rather as a political concept which is used as a negative label invoking expectations of failure and underachievement, some use it for characterization of certain groups of bilinguals. From a psychological point of view, it is acceptable that monolinguals can also become semilingual in their only language if the environment does not support their linguistic development. In the same sense, double-semilingualism is the consequence of a subtractive bilingual situation, in which the conditions required for the development of the first language are lacking, and the second language is acquired by compulsion.

\section{Surface and cognitive linguistic competence and common underlying proficiency}

Concerning speech development in bilinguals, mention is often made of two important levels of linguistic proficiency: surface (also called communicative) linguistic competence and cognitive linguistic competence. The distinction between these two aspects of language ability was made by Cummins (1979a). He labelled them as BICS (Basic Interpersonal Communicative Skills) and CALP (Cognitive Academic Language Proficiency). The difference is based on observations made both in Europe (Skutnabb-Kangas \& Tuokomaa, 1976) and in North America (Cummins, 1981, 1984). It was remarked that immigrant children often appear to teachers to be fluent in the language of instruction (their second language) but still show poor performance in verbal tests in both of their languages, 
for example in Finnish and Swedish in Sweden, or in English in Canada. They are also below age expectations in psychological assessment situations. By introducing the concepts of BICS and CALP, Cummins was able to explain this discrepancy between the different time periods needed by immigrant children to acquire conversational fluency in their second language as compared to grade appropriate academic language skills in that language.

In psychological terms, surface linguistic competence denotes the acquisition of a language to a level enabling successful communication in everyday situations, especially when supported by nonverbal elements of the situation. This type of competence is characterized by correct pronunciation, basic vocabulary, and the knowledge of basic grammar rules. It occurs in a meaningful social context which is not very demanding cognitively. Cognitive linguistic competence denotes a higher level of fluency, which enables the speaker to think in the language. It is required in context-reduced situations. This type of competence implies the ability to perform intellectual operations using linguistic means and is characterized by comprehension of verbally expressed abstract notions, familiarity with synonyms and an ability to analyze complex linguistic communication. Besides these characteristics, this type of competence also determines successful communication in verbally saturated situations, leading to achievements in the more cognitively demanding forms of school education (e.g. Göncz, 2007).

Surface language competence develops by the age of five in a speaker's first language, and can be reached within two years in the second language as well. By contrast, cognitive linguistic competence follows the growth of intelligence, thus taking at least five years to develop in the second language (Göncz, 2007). When bilinguals must communicate in a language in which they are only superficially competent, their intellectual functioning remains below their capacities.

In Vygotsky's theory on the relation between language and thought (1962), "internal speech" which results from internalized egocentric speech, is similar to the concept of cognitive linguistic competence. The BICS/CALP distinction also appears under different terms in developmental and educational psychology (communicative and analytic competence, embedded and disembedded language, utterance and text), but the essential distinction always refers to the extent to which the meaning being communicated is supported by extralinguistic cues (gestures, facial expressions) or reliant on linguistic cues that are independent of communicative context.

The major critiques (e.g. Edelsky, 1990; Edelsky et al. 1983; Martin-Jones \& Romaine, 1986) stressed, that the distinction attributes lack of scholastic achievement among bilingual (minority) students to low CALP (which is an artefact of the improper measurement of "test-wiseness") rather than to inappropriate schooling, thereby promoting a "deficit theory". Despite these comments, the distinction has exerted important impact on educational policies 
the entire world over. There is also evidence of its linguistic reality: Biber (1986) and Corson (1995) found significant lexical differences between conversational interactions in English as compared to academic uses of English.

Cummins (e.g. 1984, 2000) advanced the BICS/CALP distinction into a larger theory known as CUP (Common Underlying Language Proficiency), parallel with his interdependence hypothesis (see below). CUP focuses upon the relationship between language and thought. Cummins believes that in the course of learning one language a child acquires skills, ideas and concepts that can be drawn from when working in another language. CUP provides a basis for the development of both languages. It is an integrated source of thought for bilinguals' languages and any expansion of this set occurring in one language will have a beneficial effect on the other language(s). This is why it becomes increasingly easier to learn further languages. (For considerable empirical evidence that emerged to support these effects, mostly within the framework of bilingual education, see e. g. Rossell \& Baker, 1996; Cummins \& Corson, 1998 and Cummins, 1999). Cummins' common underlying proficiency model (Figure 2) can be visualized as two icebergs separate above the water line but fused underneath the surface, meaning that the surface features of two languages (e.g. pronunciation and vocabulary) may be different but the CALP skills (e.g. semantic and functional meaning) are common across languages. The CUP model is also a (hierarchical) model of bilingual memory, a way of thinking about how languages and concepts are stored in the bilingual brain. According to this model, bilingual speakers have separately stored proficiencies in each language and each language through working (short term) memory have access to long-term memory which is not language specific. In other words, the use of the first or second language is informed by the working memory, but the concepts are stored as underlying proficiency; each language is connected to, and interacts with, the conceptual system. 
Figure 2 Dual iceberg model

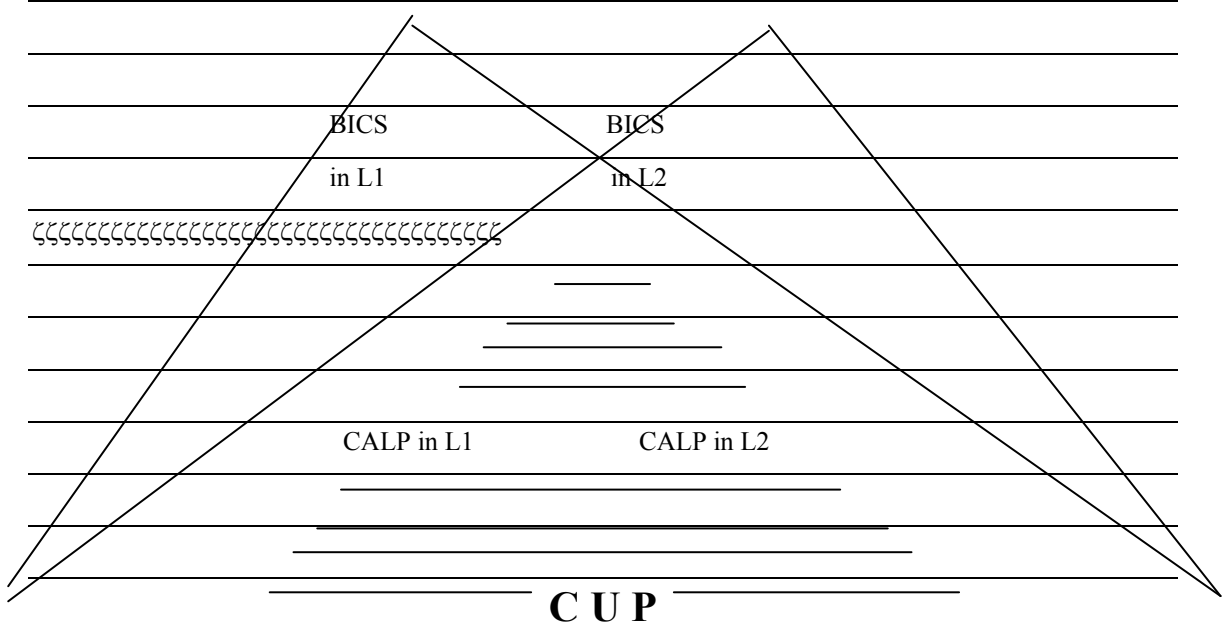

(integrated source of thought for bilingual's languages)

\section{L1-first language}

L2-second language

BICS-Basic Interpersonal Communicative competence

CALP-Cognitive Academic Language Proficiency

CUP-Common Underlying proficiency

The first pick above the waterline represents a bilingual's social language in the first language (BICS in L1) and the second pick represents a bilingual' social language in the second language (BICS in L2). Beneath the waterline is one firm iceberg. One side shows a bilingual's academic language proficiency in the first language (CALP in L1) and the other side shows academic proficiency in the second language (CALP in L2). In the middle academic proficiency in first and the second language intersect. The overlapping area is called Common Underlying proficiency (CUP). 


\section{The interdependence hypothesis}

Cummins stated the interdependence hypothesis (also known as the developmental interdependence hypothesis) in 1981 as follows:

To the extent that instruction in Lx is effective in promoting proficiency to $\mathrm{Lx}$, transfer of this proficiency to Ly will occur provided there is adequate exposure to Ly (either in school or environment) and adequate motivation to learn Ly (p. 29).

Several aspects of this hypothesis have been mentioned earlier (e.g. Cummins, 1976; 1979a, 1981; Skutnabb-Kangas \& Toukomaa, 1976), but later it was built in into the CUP model as the interdependence principle, which is one of the basic beliefs among advocates of bilingual education (Cummins, 1998). It is also strongly connected with Cummins' threshold hypothesis (Cummins, 1979b) and the notion of semilingualism. In Garcia's (2009) view the interdependence hypothesis is one of Cummins' theoretical constructs which "combine psycholinguistic perspectives with social perspectives that enable us to see the effects of the social context on bilingualism" (p.71).

The hypothesis of language proficiency interdependence in bilinguals examines the development of the first and second languages when learned successively. According to this hypothesis, linguistic competence attainable in the second language is a function of competence already achieved in the first. If first-language competence is already low as a result of insufficient developmental stimulation, and then intensive study of a second language is introduced, the second language will hinder further development of the first, thereby also limiting development of the second. If first-language competence is already high, and the conditions for further development of the first-language exist, intensive study of a second language is the most effective way to acquire functional bilingualism without an impairment in linguistic development. In other words, a cognitively and academically beneficial form of bilingualism can be achieved only on the basis of adequately developed first language (L1) skills.

Empirical research data on the effectiveness of different forms of bilingual education (Rossell \& Baker, 1996; Cummins \& Corson, 1998; Thomas \& Collier, 2002) and on research studies that documented transfer of cognitive/academic or literacy-related skills across languages (Jiang \& Kuehn, 2001; Yamashita, 2002) support this hypothesis. However, more research is needed for specifying the type, amount and direction of transfer across closely related or more distant languages at different stages of development. 


\section{The threshold hypothesis}

Surface and cognitive linguistic competence (together with semilingualism and common underlying proficiency) play an important role in Cummins' threshold hypothesis (Cummins, 1976, 1979b), which attempts to explain the possible effects of early bilingualism. According to Cummins, bilingual competence is an intermediary variable between a bilingual situation and the quality of its effects on psychological development and on cognitive development in particular. $\mathrm{He}$ identified two threshold levels of bilingual competence, the lower and the higher level. As Cummins (1976) wrote, attainment beyond the lower threshold "would be sufficient to avoid retardation, but the attainment of a second, higher level of bilingual competence might be necessary to lead to accelerated cognitive growth" (p. 24). His ideas can be represented graphically as in Figure 3, like floors in a house. In other words, Cummins holds that in an additive bilingual situation where the development of both languages is sufficiently motivated and leads to high competence in both, positive effects of bilingualism can be expected. Because a bilingual's relationship with two cultures and ethnic groups can be as intense as the monolingual's relationship with only one, certain cognitive potentialities will be realized more fully than in an exclusively monolingual setting. In dominant bilingualism, in which one language is used most frequently and at native level, bilingualism is not expected to substantially influence intellectual development. In a subtractive situation, in which bilingualism is unwelcome, unfavourable conditions for psychological development and functioning accumulate (cognitive linguistic competence is not achieved in either of the languages) and the effects of the environment that manifest through language diminish. If the lower threshold of bilingual competence can be surpassed, these negative effects disappear; upon reaching the upper threshold, bilingual experience begins to stimulate intellectual development. 
Figure 3 Threshold hypothesis

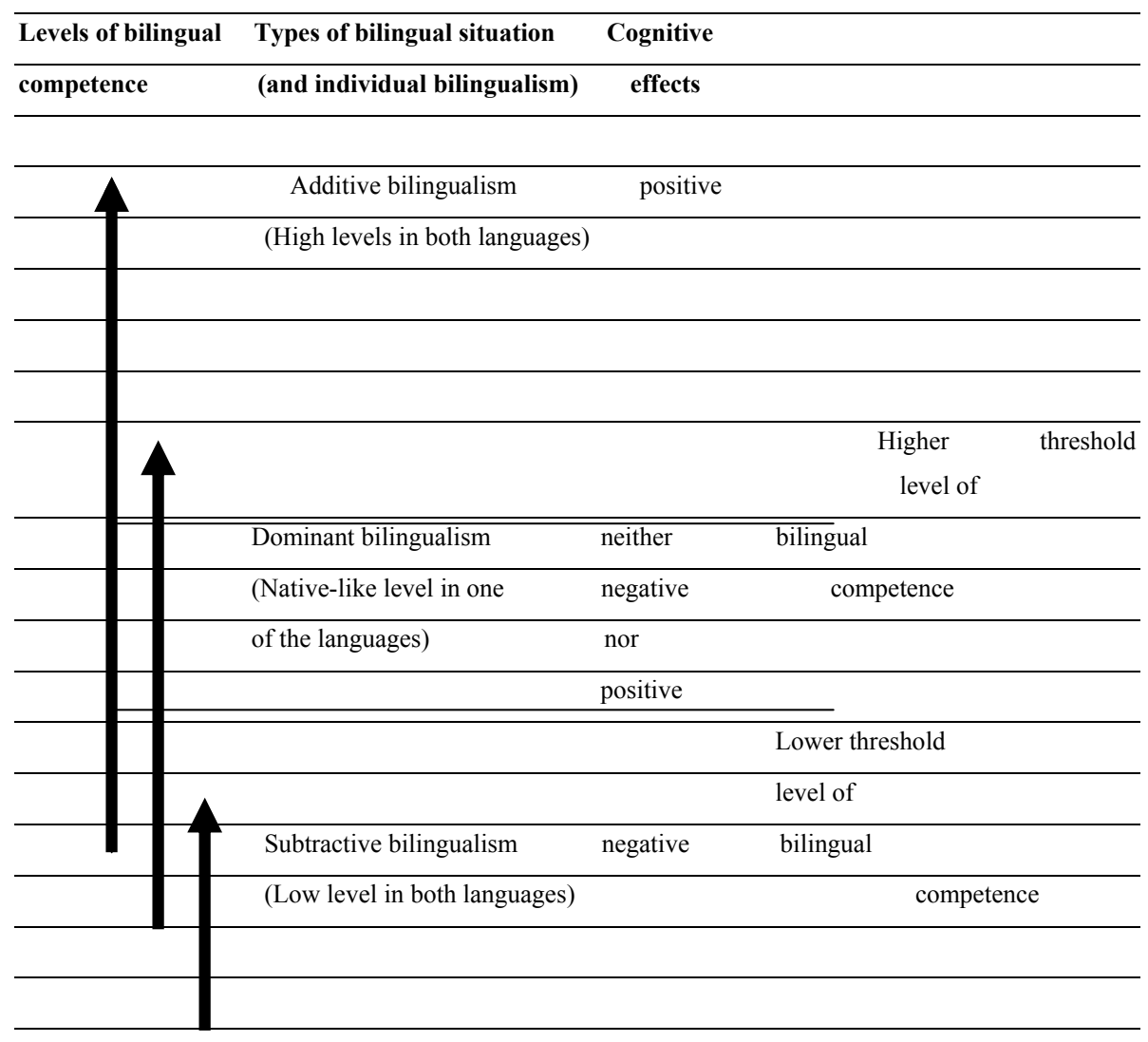

$\begin{array}{lll}\text { H } & \text { P } & \text { L }\end{array}$

H-high

P-partial

L-low 
The threshold hypothesis is a theoretical description and, as such, has several limitations. It has been criticized for various reasons. For example, MacSwan (2000) thinks that it "should be abandoned on empirical, theoretical, and moral grounds" (p. 3). Takakuwa (2005) also claims, that since "the threshold levels are relative, the threshold hypothesis is either meaningless or trivially true...It is even possible that the lower threshold level found in a study is higher, in the absolute sense, than the higher threshold level found in another (p. 2223). On the other hand, many researchers assert that the hypothesis is supported by research (e.g. Cummins, 2000; Göncz, 1981; Ricciardelli, 1993). Despite its limitations, the hypothesis has stimulated support for developing bilingualism. It remains a useful tool in explaining the development of bilingual learners, and suggests that both languages must be given an opportunity to develop if there is to be a long-term positive impact.

\section{CONCLUSION}

Bilingualism has become internationally important not only for the reason that more than half of the world's population lives in some form of a bilingual or multilingual linguistic environment, but also because of the increasing interdependence between countries, regions and continents, and because of increasing concern about preserving linguistic and cultural diversity (Göncz, 2014). It deserves much more attention on the part of psychologists, who should not disregard the difficult-to-study experience of millions of people. Despite what is already known about very different aspects of bilingualism (see, for example, some of the excellent introductions to bilingualism by Altarriba \& Heredia, 2008; Bhatia \& Ritchie, 2004; Bialystok, 2001; Garcia, 2009; Kroll \& De Groot, 2005; Myers-Scotton, 2005; Paradis, 2004, to mention only a few), much more research needs to be conducted on the topic.

In future research, emphasis should be placed not only on the psychological development of bilinguals per se, but rather as a means of shedding light on issues of general development. Future research should concentrate on the mechanisms that best reverse language shift, thereby promoting the maintenance of all languages spoken within a community. More efficient language teaching methods are also urgently needed. Very promising fields of future research are also bilingualism and aging, bilingualism and emotions, and bilingual episodic (autobiographical) memory. 


\section{REFERENCES}

Altarriba, J. (2002). Bilingualism: Language, memory, and applied issues. In Online Readings in Psychology and Culture (Unit 4, Chapter 4), (http://orpc.iaccp.org) International Association for Cross-Cultural Psychology.

Altarriba, J. \& Heredia, R. R., Eds. (2008). An Introduction to bilingualism: Principles and processes. New York \& London: Erlbaum.

Bain, B. (1974). Bilingualism and cognition. Toward a general theory. In: Carey, S. T. (Ed.). Bilingualism, biculturalism, and education. Proceedings from the Conference at College Universitaire Saint Jean (pp. 119-128). Edmonton: The University of Alberta.

Balkan, L. (1970). Les effets du bilinguisme français-anglais sur les aptitudes intellectuelles. Brussels: AIMAV.

Ben-Zeev, S. (1977). The influence of bilingualism on cognitive strategy and cognitive development. Child Development, 48, 1009-118.

Berry, R.S.Y. \& Williams, M. (2004). In at the deep end. Difficulties experienced by Hong Kong Chinese ESL learners at an independent school in the United Kingdom. Journal of Language and Social Psychology, 23, 118-134.

Bhatia, T.K. \& Ritchie, W.C., Eds. (2004). The handbook of bilingualism. Oxford: Blackwell.

Biber, D. (1986) Spoken and written textual dimensions in English: Resolving the contradictory findings. Language, 62, 384-414.

Bialystok, E. (2001). Bilinguals in Development: Language, Literacy and Cognition. Cambridge: Cambridge University Press.

Bialystok, E. (2009). Bilingualism: The good, the bad, and the indifferent, Bilingualism: Language and Cognition, 12, 3-11.

Bialystok, E. (2015). The Impact of Bilingualism on Cognition. Emerging Trends in the Social and Behavioral Sciences: An Interdisciplinary, Searchable, and Linkable Resource. 1-12 doi: 10.1002/9781118900772.etrds0340

Bialystok, E., Craik, F. I., Binns, M. A., Ossher, L., \& Freedman, M. (2014). Effects of bilingualism on the age of onset and progression of MCI and AD: Evidence from executive function tests. Neuropsychology, 28, 2, 290-304.

Bialystok, E., Craik, F.I.M. \& Freedman, M. (2007). Bilingualism as a protection against the onset of symptoms of dementia. Neuropsychologia, 45, 459-464

Bialystok, E., Craik, F.I.M. \& Ryan, J. (2006). Executive control in a modified antisaccade task: effects of aging and bilingualism. Journal of Experimental Psychology: Learning, Memory and Cognition, 32, 1341-1354.

Bialystok, E., Craik, F.I.M., Klein, R. \& Visvanathan, M. (2004). Bilingualism, aging, and cognitive control: evidence from the Simon Task. Psychology and Aging, 19, 290-303.

Cook, V. (1997). The consequences of bilingualism for cognitive processing. In: De Groot, A. M. B. \& Kroll, J.F. (Eds.). Tutorials in bilingualism: Psycholinguistic perspectives (pp. 279-299). Mahwah, N. J.: Erlbaum.

Cook, V. (2008). Linguistic contributions to bilinguals, In: . Altarriba, J. \& Heredia, R. R. (Eds.). An Introduction to bilingualism: Principles and processes (pp. 245-264), New York-London: Erlbaum.

Corson, D. (1995). Using English words. New York: Kluwer. 
Cummins, J. (1976). The influence of bilingualism on cognitive growth: A synthesis of research findings and explanatory hypothesis. Working Papers on Bilingualism, 9, $1-43$.

Cummins, J. (1978). Metalinguistic development of children in bilingual education programs: Data from Irish and Canadian Ukrainian-English programs. In: Paradis, M. (Ed.). The Fourth Locus Forum 1977 (pp.29-40). Columbia, S C: Hornbeam Press.

Cummins, J, (1979a). Cognitive/academic language proficiency, linguistic interdependence, the optimal age question and some other matters, Working Papers on Bilingualism, 19, 197-2005.

Cummins, J. (1979b). Linguistic interdependence and the educational development of bilingual children. Review of Educational Research, 49, 2, 221-251.

Cummins, J. (1981). The role of primary language development in promoting educational success for language minority students. Schooling and language minority students: $a$ theoretical framework. Los Angeles: Evaluation, Dissemination and Assessment Centre, California State University.

Cummins, J. (1984). Bilingualism and special education: issues in assessment and pedagogy, Clevedon: Multilingual Matters.

Cummins, J. (1994). The acquisition of English as a second language. In: Pritchard, R. \& Spangenberg-Urbschat, K. (Eds.). Kids come in all languages (pp. 36-62). Newark, DE: International Reading Association.

Cummins, J. (1998). Immersion education for the millennium: What have we learned from 30 years of research on second language immersion? In: Childs, M. R. \& Bostwick, R. M. (Eds.). Learning through two languages: Research and practice. Second Katoh Gakuen International Symposium on Immersion and Bilingual Education (pp. 34-47). Numazu, Japan: Katoh Gakuen.

Cummins, J. (1999). Beyond adversarial discourse: Searching for common ground in the education of bilingual students. In Ovando, C. J. \& McLaren, P. (Eds.). The politics of multiculturalism and bilingual education: Students and teachers caught in the cross-fire (pp. 126-147). Boston: McGraw-Hill.

Cummins, J. (2000) Language, Power and pedagogy. Clevedon: Multilingual Matters

Cummins, J. \& Corson, D. (Eds.). (1998). Bilingual Education. Dordrecht, The Netherlands: Kluwer Academic Publishers

Cummins, J. \& Gulutsan, M. (1974). Some effects of bilingualism on cognitive functioning. In: Carey, S. (Ed.). Bilingualism, biculturalism and education. Proceedings from the conference at Collège universitaire Saint-Jean (pp. 129-136). Edmonton: The University of Alberta.

Darcy, N. T. (1953). A review of the literature on the effects of bilingualism upon the measurement of intelligence. Journal of Genetic Psychology, 82, 21-57.

Dewaele, J.-M. (2015). Bilingualism and Multilingualism. The International Encyclopedia of Language and Social Interaction, 1- 11. doi:1002/9781118611463.wbielsi108

Dewaele, J.-M. (2008). Dynamic emotion concepts of L2 learners and L2 users: A Second Language Acquisition perspective. Bilingualism: Language and Cognition, 11, 173-175.

Diaz, R. M. (1985). The intellectual power of bilingualism. In Second Language Learning by Young Children (pp. 68-84). Sacramento, CA: Advisory Committee for Child Development Programs. 
Downing, J. \& Valtin, R. (Eds.) (1984). Language awareness and learning to read. NewYork: Springer-Verlag.

Edelsky, C. (1990). With literacy and justice for all: Rethinking the social in language and education. London: The Falmer Press.

Edelsky, C., Hudelson, S., Altwerger, B., Flores, B., Barkin, F. \& Jilbert, K.(1983). Semilingualism and language deficit. Applied Linguistics, 4, 1-22.

French, R.M. \& Jacquet, M. (2004). Understanding bilingual memory: models and data. Trends in Cognitive Science, 8, 87-93.

Garcia, O. (2009). Bilingual education in the $21^{\text {st }}$ century: a global perspective. Singapore: Wiley-Blackwell.

Genesee, F. Tucker, G. R. \& Lambert, W. E. (1975). Communication skills in bilingual children. Child Development. 46, 1010-1014.

Göncz, L. (1973). Dvojezičnost kao faktor u objektivizaciji nekih aspekata mišljenja kod dece (Bilingualism as a factor in the objectivization of some aspects of thought in children). U: Lukić, V., Vasić, S., Škarić, I. \& Hrkalović, R. (ured.). Dečji govor. Zbornik 6 Instituta za pedagoška istraživanja (pp.201-206). Beograd: Naučna knjiga.

Göncz, L. [Genc, L.]. (1981). Rana dvojezičnost i kognitivni razvoj (Early bilingualism and cognitive development). Novi Sad: Filozofski fakultet-Zavod za izdavanje udžbenika.

Göncz, L. (1985). A kétnyelvüség pszichológiája. A magyar-szerbhorvát kétnyelvüség lélektani vizsgálata (Psychology of bilingualism. Psychological investigations of Hungarian Serbo-Croatian bilingualism). Úvidék: Forum.

Göncz, L. (2007). Novija istraživanja pedagoško-psiholoških aspekata dvojezičnosti u Vojvodini. Posledice promene nastavnog jezika na školsko postignuće i moguća objašnjenja. U: Szalma, J. (ur.). Jezik, obrazovanje, nauka, kultura, zaštita ljudskih i manjinskih prava u Vojvodini i zemljama u tranziciji. Zbornik radova VANU (pp. 109-127), Novi Sad: Vojvođanska akademija nauka i umetnosti.

Göncz, L. (2014). Treba li spašavati jezike ili njihove govornike?- Opadanje biolingvističkog diverziteta kao psihološki problem - pristupna beseda. (Decrease of biolinguistic diversity as a psychological problem - inaugural speech), to appear in VANU - Godišnjak 2014, Novi Sad: Vojvođanska akademija nauka i umetnosti.

Göncz, L. \& Kodžopeljić, J. (1991). Exposure to two languages in the preschool period, metalinguistic development and the acquisition of reading. Journal of Multilingual and Multicultural Development 12, 65-81.

Göncz, L. \& Vörös, O. (2005). Hungarian in the former Yugoslavia (Vojvodina and Prekmurje), In A. Fenyvesi, (Ed.) Hungarian language contact outside Hungary (pp. 187-240). Amsterdam: John Benjamins.

Grosjean, F. (1982). Life with two languages. Cambridge, MA: Harvard University Press.

Grosjean, F. (1994). Individual bilingualism. In: The encyclopaedia of language and linguistics (pp. 1656-1660). Oxford: Pergamon Press.

Hakuta, K. \& Diaz, R. (1985). The relationship between degree of bilingualism and cognitive ability: A critical discussion and some new longitudinal data. In: Nelson, K. E. (Ed.). Children's Language (vol. 5, pp. 319-344). Hillsdale, NJ.: Erlbaum.

Hakuta, K., Ferdman, B. M. \& Diaz, R. M. (1986). Bilingualism and cognitive development: Three perspectives and methodological implications. UCLA: Center for Language Education and Research. 
Heredia, R. R. (2008). Mental models of bilingual memory. In: Altarriba, J. \& Heredia, R. R. (Eds.), An Introduction to bilingualism: Principles and processes (pp. 39-70). New York \& London: Erlbaum.

Hódi, S. (1992). A nemzeti identitás zavarai (The disorders of national identity). Újvidék: Forum.

Ianco-Worrall, A. (1972). Bilingualism and cognitive development. Child Development, 43, $1390-1400$.

Jiang, B. \& Kuehn, P. (2001). Transfer in the academic language development of post-secondary ESL students. Bilingual Research Journal, 25, 417- 436.

Klein, R. M. (2015). Is there a benefit of bilingualism for executive functioning?. Bilingualism: Language and Cognition, 18, 29-31.

Kroll, J. F., \& De Groot, A. M. B. (Eds.). (2005). Handbook of bilingualism: Psycholinguistic approaches. New York: Oxford University Press.

Lambert, W. E. (1975). Culture and language as factors in learning and education. In Wolfgang, A. (Ed.). Education of immigrant students. Toronto: OISE.

Lambert, W. E. \& Anisfeld, E. (1969). A note on the relationship of bilingualism and intelligence, Canadian Journal of Behavioural Science/Revue canadienne des Sciences du comportement, 1, 123-128

Landry, R. G. (1974). A comparison of second-language learners and monolinguals on divergent thinking tasks at the elementary school level. Modern Language Journal, 58, 10-15.

Lee, P. (1996). Cognitive development in bilingual children: a case for bilingual instruction in early childhood education. The Bilingual Research Journal, 20, 499-522.

Leopold, W. F. (1949). Speech development of a bilingual child: A linguist's record. Evanston, IL: Northwestern University Press.

Liedtke, W. W. \& Nelson, L.D. (1968). Concept formation and bilingualism. Alberta Journal of Educational Research, 14, 225-232.

Long, K. K. \& Padilla, A. M. (1970). Evidence for bilingual antecedents of academic success in a group of Spanish-American college students. Unpublished research report. Bellingham: Western Washington State College.

Macnamara, J. (1966). Bilingualism and primary education. Edinburgh: Edinburgh University Press.

MacSwan, J. (2000). The threshold hypothesis, semilingualism, and other contribution to a deficit view of linguistic minorities. Hispanic Journal of Behavioral Sciences, 22, 3-45.

Marian, V. (2008). Bilingual research methods. In Altarriba, J. \& Heredia, R. R. (Eds.). An Introduction to bilingualism: Principles and processes (pp.13-38). New York \& London: Erlbaum.

Marian,V. \& Neisser, U. (2000). Language-dependent recall of autobiographical memories. Journal of Experimental Psychology: General, 129, 361-368.

Martin-Jones, M. \& Romaine, S. (1986). Semilingualism: a half-baked theory of communicative competence. Applied linguistics, 7, 26-38.

Matsumoto, D. \& Juang, J. (2008). Culture and psychology ( $4^{\text {th }}$ ed.). Belmont, CA: Thomson/ Wadsworth.

May, S. \& Hill, R. (2003). Bilingual/Immersion Education: Indicators of Good Practice. Milestone Report 2. Hamilton: Wilf Malcolm Institute of Educational Research, School of Education, University of Waikato. 
May, S., Hill, R., \& Tiakiwai, S. (2004). Bilingual/immersion education: Indicators of good practice. Wellington: Ministry of Education.

Mohanty, A. K. (1994). Bilingualism in a Multilingual Society. Psychosocial and Pedagogical Implications. Mysore: Central Institute of Indian languages.

Moilanen, I. \& Myhrman, A. (1989). Acclimatization of relocated children and adolescents. Zeitschrift für Kinder- und Jugendpsychiatrie, 17,10-16

Myers-Scotton, C. (2005). Multiple Voices: An introduction to bilingualism. Malden, MA: Blackwell.

Nguyen, A.-M.T. \& Benet-Martinez, V. (2007). Biculturalism Unpacked: Components, Measurement, Individual Differences, and Outcomes. Social and Personality Psychology Compass, 1, 101-114.

Paradis, M. (1997). The cognitive neuropsychology of bilingualism. In: De Groot, A. M. \& Kroll, J. F. (1997). (Eds.). Tutorials in bilingualism: Psycholinguistic perspectives (pp. 331-354). Mahwah, N.J.: Erlbaum.

Paradis, M. (2004) Neurolinguistic aspects of bilingualism. Amsterdam: John Benjamins.

Pavlenko, A. (1999). New approaches to concepts in bilingual memory. Bilingualism: Language and Cognition, 2-3, 209-230.

Pavlenko, A. (2008). Emotion and emotion-laden words in the bilingual lexicon. Bilingualism: Language and Cognition, 11, 147-164

Peal, E. \& Lambert, W. E. (1962). The relation of bilingualism to intelligence, Psychological Monographs: General and Applied, 76, 1-23.

Piaget, J. (1964). Le language et la pensée du point de vue génétique [Language and thought from a genetic viewpoint]. In Piaget, J. (Ed.) Six études de psychologie [Six studies in psychology] (pp. 100-113). Genève: Editions Gonthier.

Ricciardelli, L. A. (1992). Creativity and bilingualism. Journal of Creative Behavior, 26, 242-254.

Ricciardelli, L. A. (1993). An investigation of the cognitive development of Italian-English bilinguals and Italian monolinguals from Rome. Journal of Multilingual and Multicultural Development, 14, 345-346.

Ronjat, J. (1913). Le developpement du langage observé chez un enfant bilingue. Paris: Champion.

Rossell, C.H. \& Baker, K. (1996). The effectiveness of bilingual education. Research in the Teaching of English, 30, 7-74.

Schrauf, R. W. (2000). Bilingual autobiographical memory: Experimental studies and clinical cases. Culture \& Psychology, 6, 387-417.

Schrauf, R. W. (2008). Bilingualism and aging In Altarriba, J. \& Heredia, R. R. (Eds.). An Introduction to bilingualism: Principles and processes (pp.105-127). New York \& London: Erlbaum.

Schrauf, R. W., Pavlenko, A. \& Dewaele, J-M. (2003). Bilingual episodic memory: An introduction. International Journal of Bilingualism, 7, 221-223.

Skutnabb-Kangas, T. (1984). Bilingualism or not: the education of minorities. Clevedon,Avon: Mutilingual Matters.

Skutnabb-Kangas, T. \& Toukomaa, P. (Eds.). (1976) Teaching migrant children's mother tongue and learning the language of the host country in the context of the sociocultural situation of the migrant family. Helsinki: Finnish Commission for UNESCO.

Takakuwa, M. (2005). Lessons from a paradoxical hypothesis: A methodological critique of the threshold hypothesis. In J. Cohen, K. T. Mc Alister, K. Rolstad \& J. MacSwan (Eds.). 
Proceedings of the 4th International Symposium on Bilingualism (pp. 2222-2232). Somerville, MA: Cascadilla Press.

Thomas, W. P., \& Collier, V. P. (2002). A national study of school effectiveness for language minority student's long-term academic school achievement (Final Paper No. 1.1). Santa Cruz, CA: University of California. Center for Research an Education, Diversity \& Excellence.

Tsai, T. \& Yaden, D. B. (2004). The effects of bilingual and multilingual environments on the metalinguistic awareness of young children. Paper presented at Annual Meeting of American Educational Research.

Vuorenkoski, L. Kuure, O., Moilanen, I., Penninkilampi V.\& Myhrman, A. (2000). Bilingualism, school achievement, and mental well being. Journal of Child Psychology and Psychiatry, 4, 261-266.

Vuorenkoski, L., Moilanen, I., Penninkilampi V., Myhrman, A. Kuuer, O., Penninkilampi, V. \& Kumpulainen, E. (1998). Long-term mental health outcome of returning migrant children and adolescents. European Child and Adolescence Psychiatry,7, 219-224.

Vygotsky, R.L. (1962). Thought and language. Cambridge, MA: M.I.T. Press.

Wei, L. \& Moyer, M., Eds. (2008). Blackwell guide to research methods in bilingualism and multilingualism. Oxford: Blackwell.

Whorf, B. L. (1956). Language, thought and reality. Cambridge: Technology Press-New York: Wiley.

Yamashita, J. (2002). Mutual compensation between L1 reading ability and L2 language proficiency in L2 reading comprehension. Journal of Research of Reading, 25, 81-95. 
Lajos Göncz

\title{
DVOJEZIČNOST I RAZVOJ: PSIHOLOŠKI PRISTUP
}

\begin{abstract}
SAŽETAK
Istraživanja o odnosu dvojezičnosti i psihičkog razvoja mogu se klasifikovati na različite načine. Ovaj prikaz je usmeren na dve grupe pitanja: prvo, na empirijske dokaze da je dvojezičnost povezana sa mnogim aspektima psihičkog razvoja, i drugo: na holistička i parcijalna objašnjenja uticaja dvojezičnosti na razvoj ličnosti uopšte ili na neke aspekte razvoja. U vezi sa prvom grupom pitanja, u radu je naglasak stavljen na novije dokaze o povezanosti dvojezičnosti sa egzekutivnim funkcijama i procesima memorije. Holistička objašnjenja najčešće polaze od razlikovanja aditivne i subtraktivne dvojezične situacije i kao njen rezultat pretpostavljaju širok spektar promena $u$ ličnosti. Za objašnjenje ove povezanosti korišćeni su pojmovi psihologije učenja (posebno pojmovi klasičnog i instrumentalnog uslovljavanja) i motivacije. Parcijalna objašnjenja mogu se naći u pojmovima kao što su polujezičnost nasuprot površinskoj i kognitivnoj jezičkoj kompetenciji i u hipotezama kao što su: međuzavisnost jezičkih kompetencija kod dvojezičnih osoba i Kaminsova (Cummins) hipoteza praga. Zaključeno je da su saznanja u vezi sa dvojezičnim razvojem i funkcionisanjem bogat izvor da se podrobnije rasvetle određena pitanja psihičkog razvoja uopšte. Buduća istraživanja trebala bi da se posebno posvete rasvetljavanju mehanizama koji omogućavaju da se zaustavi zamena jezika (pitanje je od posebnog značaja zbog ubrzanog nestajanja jezičke raznolikosti), istraživanjima efikasnijih metoda za podučavanje jezika, kao i odnosa dvojezičnosti i starenja, dvojezičnosti i emocija i dvojezičnosti i autobiografske memorije.
\end{abstract}

Ključne reči: dvojezičnost, psihički razvoj, nepoželjni i poželjni uticaji dvojezičnosti 